DOI dx.doi.org/10.24866/7444-4707-6/395-403

В.T. Старожилов

\title{
НОВАЯ КОНЦЕПЦИЯ ЦЕНТРАЛИЗАЦИИ ПОЧВЕННО- ЛАНДШАФТНЫХ ИССЛЕДОВАНИЙ И ПРАКТИЧЕСКАЯ ЕЁ РЕАЛИЗАЦИЯ В ТИХООКЕАНСКОМ ЛАНДШАФТНОМ ПОЯСЕ СЕВЕРНОЙ ПАЦИФИКИ
}

Освоение Дальнего Востока и в частности территории выделенного нами ранее Тихоокеанского ландшафтного пояса северной Пацифики (рис. 1), связано с грандиозными задачами поставленными правительством перед федеральными органами и в том числе перед Дальневосточным федеральным университетом. Выполнение задач в той или иной степени связано с проблемой сохранения природы, ее охраной, сохранением экологического потенциала территорий, мониторингом состояния педосферы, атмосферы, гидросферы и в целом безопасности территорий. Все это можно выполнить с помощью привлечения новых технологий, в частности связанных с анализом, синтезом, оценкой цифровых векторных ландшафтных материалов и централизацией ландшафтных и агроландшафтных исследований и практики освоения территорий.

Однако на сегодняшний день мы наблюдаем ограниченное количество работ по этой тематике и видим в целом, несмотря на актуальность учета природных условий при планировании и проектировании отраслевого освоения территорий ландшафтной сферы, недостаточное внимание со стороны государственных органов к этим вопросам, что не соответствует требованиям современных наук о природе

Районы нового освоения, относящиеся к горным и равнинным классам ландшафтам, характеризуются как территории с повышенной суровостью и напряженностью климатических ресурсов, сложным геологическим и геоморфологическим строением. Поэтому уже на стадии планирования и проектирования как отдельных предприятий соответствующих отраслей, так и формирования стратегического видения их регионального устойчивого развития, необходимо учитывать не только отраслевые карты, но и применять оцифрованные среднемасштабные картографические ландшафтные и агроландшафтные материалы. 
В целом же ландшафтная изученность Дальнего Востока, особенно это относится к изученности агроландшафтов, все еще остается недостаточной. Это обусловлено различными причинами: объективная причина повышенная контрастность и сложность ландшафтной дифференциации, требующая специальных приемов структурно-генетического и функционального методов исследования, построения особой модели организации ландшафтов, и субъективная - отсутствие в регионе ландшафтной школы соответствующего уровня. Ближайший академический Институт географии Сибири и Дальнего Востока (г. Иркутск) своими исследованиями почти не охватывал Тихоокеанский ландшафтный пояс и позже в его названии осталась только Сибирь.

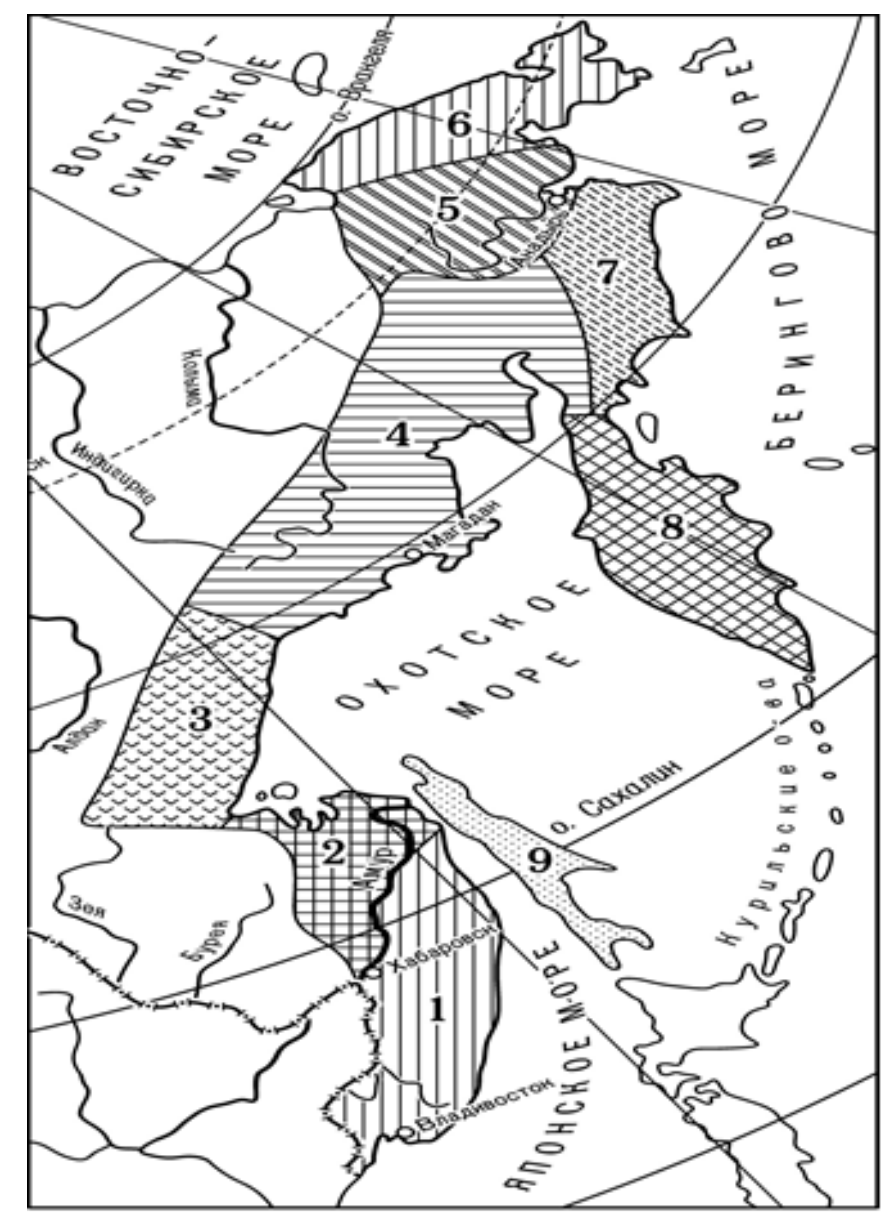

Puc. 1. Тихоокеанский ландшафтный пояс России [4].

Области пояса: 1. Сихотэ-Алинская; 2. Нижнеамурская; 3. Приохотская; 4.Колымская;

5. Анадырьская; 6. Чукотская; 7. Корякская; 8. Камчатская; 9. Сахалинская

Отсутствие Тихоокеанской ландшафтной школы отразилось в итоге на уровне ландшафтных исследований, подготовке специалистов и в целом применения ландшафтного подхода при освоении территорий. Пово- 
рот государства к планомерному освоению территорий Тихоокеанской России влечет за собой решение природно-охранных, экологических, в целом отраслевых природопользовательских и др. проблем на основе применения передовых ландшафтных технологий. В итоге по предложению государства в Дальневосточном федеральном университете был создан Тихоокеанский международный ландшафтный центр (далее ТМЛЦ). Его организация и функционирование, в свою очередь, определили необходимость, в связи с многоотраслевым природопользованием, структурирование ландшафтных исследований и централизацию их по отраслевым направлениям. Они разные. Одним из центров является почвенноландшафтный и предлагается его выделить в особый сектор и назвать его Тихоокеанским почвенно-ландшафтным сектором. Основой сектора является кафедра почвоведения ШЕН ДВФУ и Тихоокеанский международный ландшафтный центр.

\section{Методологическая научная и практическая основа}

\section{Тихоокеанского почвенно-ландшафтного сектора}

\section{Тихоокеанского международного ландшафтного центра ШЕН ДВГУ}

Научной ландшафтной основой централизации почвенноландшафтных исследований рассматривается ландшафтная география и в целом ландшафтный подход с применением ландшафтной индикации и мониторинга геосистем в рамках изучения сбалансированного и экологически безопасного развития территорий. Ландшафтному анализу подвергаются ландшафтные геосистемы различных рангов и в конечном итоге дается та или иная географическая практическая оценка соответствующего географического пространства, а полученные результаты анализа, синтеза и оценки применить для решения соответствующих производственно- хозяйственных задач вплоть до ландшафтов ранга ландшафтной сферы.

При этом важно то, что современные почвенно-ландшафтные материалы можно получить только в содружестве специалистов: математиков, физиков, химиков, географов, климатологов, гидрологов, почвоведов и др. Дальневосточный федеральный университет это идеальная организация, где имеет место сочетание многопрофильных специалистов, есть потенциал возможностей разработок новых технологий. Поэтому мы утверждаем, что ДВФУ это идеальная площадка для организации централизованных почвенно-ландшафтных исследований и подготовки условий подго- 
товки специалистов в этой области. Это можно сделать только на уровне самостоятельного структурного подразделения ДВФУ (почвенноландшафтного сектора кафедры почвоведения и ТМЛЦ). При организации сектора нужно учитывать то, что такие сектора в Тихоокеанской России отсутствуют, их аналогов нет, он может быть организован впервые, перед ним ставятся задачи федерального уровня и он должен иметь федеральное значение в рамках структурного подразделения федерального университета. ДВФУ. Обладает мощным научным разнопрофильным творческим потенциалом, может выступать гарантом в решении научноисследовательских, практических задач поставленных правительством России по освоению Дальнего Востока в области почвоведения на основе ландшафтной географии с одновременной подготовкой условий для формирования кадрового состава на основе обучения студентов.

Ландшафтная информационная база методологии работ сектора основывается на результатах многолетних научных и практических исследований в сфере геолого-географического изучения и векторно-слоевого ландшафтного картографирования крупных региональных (Приморского, Сахалинского и др.[1, 2, 7 - 10) и локальных [3] звеньев Тихоокеанского ландшафтного пояса России (рис. 1) [4].

Составлены по отдельным регионам (например, Приморскому краю) векторные слоевые ландшафтные карты масштабов 1: 500 000, 1: 1000000 и др., это создало предпосылки для их применения в качестве основы мониторинга почвосистем по выделам ландшафтов. То есть ландшафтному анализу подвергаются векторно-слоевые ландшафтные геосистемы различных рангов, и в конечном итоге дается та или иная практическая оценка пространства ландшафтной сферы, а полученные результаты анализа, синтеза и оценки можно применять для решения производственно-хозяйственных задач $[5,6]$.

Почвено-ландшафтные исследования Тихоокеанского почвенноландшафтного сектора могут основываться на применении методологии сопряженного анализа межкомпонентных и межландшафтных связей на основе учета окраинно-континентальной дихотомии, изучения орографического, климатического и фиторастительного факторов, а также применения векторно-слоевого ландшафтного картографирования. Применение такой методологии позволит создать на примере Приморского края ландшафтно-почвенную основу для индикации и мониторинга систем. 
При комплексной оценке централизованного применения ландшафтного метода как основы комплексной оценки почвопользования и преобразований ландшафтов должен применяется метод ландшафтной индикации. Он включает исследование индикаторов и индикационных связей, отражающих объекты индикации, обусловленных антропогенной трансформацией, разработкой мер по охране природной среды. В процессе ландшафтных исследований территории наряду с локальными индикаторами почвами, растительностью, рельефа, геологии, климата - важное значение имеет и интегральный индикатор - специфика морфологической структуры.

Bce, что происходит в ландшафтах - происходит на определенной площади. Для получения данных по площадям и свойствам природных ландшафтов региона необходимо иметь векторно-слоевую морфологическую ландшафтную карту. Такая карта составлена на примере Приморского края, подсчитаны площади выделенных на ней выделов ландшафтов, на основе этих данных подсчитывались соотношения площадей индикаторов модифицированных и природных ландшафтов. Их выявление и анализ - основное при определении степени трансформации ландшафтов и при определении природопользовательских последствий и природоохранных мероприятий. В условиях возрастания роли природоохранного фактора и изучения экологических рисков ландшафтная индикация выступает как основа выбора главного направления или даже стратегии хозяйствования.

Деятельность Тихоокеанского почвенно-ландшафтного сектора направлена на следующие направления:

- централизацию методических основ, оказание методической помощи по почвенно-ландшафтным направлениям;

- создание условий для устойчивого безопасного почвенноландшафтного развития Тихоокеанской России;

- формирование эффективной информационной среды на базе современных технологий и разработок, связанных с обработкой и хранением информации, доступной лицам, принимающим решения в сфере почвопользования, с целью повышения качества принимаемых решений;

- совершенствование системы принятия решений в сфере почвопользования посредством реализации экспертных функций сектора;

- содействие совершенствованию нормативно-правового поля в сфере почвопользования и управления; 
Научная деятельность: разработка почвенно-ландшафтных прогнозов последствий хозяйственной деятельности; разработка моделей районирования Тихоокеанской России и отдельных ее регионов; создание векторных ландшафтных отраслевых основ почвопользования;

Методическая деятельность: сектор способствует научнометодическому обеспечению устойчивого территориального развития Тихоокеанской России;

Консалтинговые услуги: сектор оказывает инженерные и консалтинговые услуги организациям с целью оптимизации почвопользования;

Экспертная деятельность: сектор проводит профессиональные почвенно-ландшафтные и иные экспертизы, экологический аудит для действующих и планируемых объектов хозяйствования, а также территорий (природных и преобразованных ландшафтов) и береговых зон и акваторий (морских и речных) с целью определения соответствия проекта научным основам устойчивого природопользования, выявления ключевых научнотехнических и технологических рынков проекта, а также связанных с ними эколого- и почвоенно-ландшафтных проблем развития современных ландшафтов и разработки практических рекомендаций по их устранению, а также устойчивого развития территорий и акваторий;

Научно-образовательная: сектор оказывает научно-образовательные услуги на уровне осуществления учебных и производственных практик для обучающихся по направлению подготовки «География», «Экология и природопользование», «Ландшафтная архитектура», а также по другим специальностям и направлениям подготовки, востребованным на рынке труда; повышение квалификации специалистов, работающих в сфере ландшафтного планирования, работников государственных и муниципальных предприятий, разрабатывает ландшафтные образовательные программы;

Просветительская деятельность: сектор осуществляет просветительскую деятельность по популяризации идей о ландшафте и реализации Международной конвенции о ландшафте, «Продвижение» Центра и его деятельности в СМИ, популяризация научной информации, привлечения внимания общественности к ландшафтно-экологическим проблемам Тихоокеанской России. Проведение научно-практических конференций и круглых столов краевого, федерального и международного уровней по соответствующей тематике. 
Предлагается централизовать почвенно-ландшафтное направление в Тихоокеанской России и организовать на базе кафедры почвоведения ДВФУ и ТМЛЦ Тихоокеанский почвенно-ландшафтный сектор Международного ландшафтного центра и назвать его Тихоокеанским почвенноландшафтным сектором. Организация такого сектора поможет повысить практическую реализацию почвенно-ландшафтного подхода в освоении Тихоокеанской России и повысить планку совместной подготовки специалистов нового поколения и современного информационного уровня.

В целом на сегодняшний день в результате применения методологии сопряженного анализа межкомпонентных и межландшафтных связей на основе учета окраинно-континентальной дихотомии, изучения орографического, климатического и фиторастительного факторов, обуславливающих генетическое и географическое единство ландшафтных территорий, а также применения векторных приемов ГИС и векторно-слоевого ландшафтного картографирования на примере Приморского края, Сахалинской области и других звеньев Тихоокеанского ландшафтного пояса в ДВФУ в рамках ландшафтной географии создана ландшафтная база, разработана методика векторного слоевого ландшафтного районирования и изучения иерархической структуры и внутреннего географического содержания таксонов такого районирования в рамках горного ландшафтоведения. Разработанная методика применена на практике, в том числе при составлении ландшафтных карт Приморского края и карты Тихоокеанского ландшафтного пояса.

Предлагаем применять компьютерную технологию векторного слоевого картографирования и методику компьютерного пользования векторно-слоевыми ландшафтными картами и уже составленные векторнослоевые ландшафтные карты в качестве «платформы» и основы для профессиональных работ Тихоокеанского почвенно-ландшафтного сектора. Использование уже разработанной ландшафтной платформы во многом скорректирует направления ландшафтной деятельности сектора. В целом сектор поможет в решении поставленных правительством практических задач по освоению территорий Тихоокеанской России.

\section{Литература}

1. Старожилов В.Т. Ландшафты Приморского края и использование ландшафтного подхода в оценке экологических проблем минерально- 
сырьевого природопользования: моногр. - Владивосток : Изд-во Дальневост. федер. ун-та, 2011. 225 с.

2. Старожилов В.Т. Общее ландшафтоведение и использование ландшафтного подхода в экологическом мониторинге природопользования: курс лекций / Старожилов В.Т. - Владивосток: Изд-во Дальневост. Федерал. ун-та, 2011. 286с.

3. Старожилов В.Т., Ознобихин В.И. Ландшафтные геосистемы о. Русский Приморского края [Электронный ресурс] // Современные исследования в естественных науках : материалы II Междунар. науч. конф., 2628 авг. 2015 г., Владивосток. Владивосток : Изд-во Дальневост. ун-та, 2015. C. 32 - 35.

4. Старожилов В.Т. Тихоокеанский окраинно-континентальный ландшафтный пояс как географическая единица Тихоокеанской России и вопросы природопользования / В. Т. Старожилов // Проблемы региональной экологии. 2013. № 5. С. 1 - 10.

5. Старожилов В.Т. Процессы механической деградации почв в ландшафтах Приморья / Дербенцева А. М., Старожилов В.Т., Евсеев А. Б., Ткаченко В. И., Степанова А. И. моногр. - Владивосток : Изд-во Дальневост. ун-та, 2009. 86 с.

6. Старожилов В.Т. Техногенные изменения ландшафтов, обусловленные промышленным производством в Приморском крае / Старожилов В.Т., Дербенцева А. М., Крупская Л. Т., Евсеев А. Б // Экологические системы и приборы. 2009. № 6. С. 52 - 55.

7. Старожилов В.Т. Ноосферные проблемы, структура и пространственная организация ландшафтов дальневосточных территорий (на примере Приморского края)/ Старожилов В.Т. В сборнике: Ноосферные изменения в почвенном покрове Материалы Международной научнопрактической конференции. Дальневосточный государственный университет; Под общей редакцией: А. М. Дербенцева. 2007. С. 31 - 37.

8. Старожилов В.Т. Региональные компоненты и факторы структуры и пространственной организации ландшафтов юга Дальнего Востока (на примере Приморского края). Москва, 2008.

9. Старожилов В.Т. Статистический анализ прстранственного распределения ландшафтов окраинно-континентальных геосистем Тихоокеанской России / в сб. эколого-геоморфологические исследования в урбанизированных и техногенных ландшафтахъ (Арчиковские чтения - 2015). 
Сборник материалов Всероссийской летней молодежной школыконференции, посвященной 90-летию со дня рождения доктора географических наук, профессора Емельяна Ивановича Арчикова. ФГБОУ ВПО «Чувашский государственный университет имени И.Н. Ульянова»; Российский фонд фундаментальных исследований; Чувашское республиканское отделение ВОО «Русское географическое общество»; главный редактор И. В. Никонорова. 2015. С. 102 - 113.

10. Старожилов В.Т. Ландшафтное картографирование территорий Приморского края/Известия Российской академии наук. Серия географическая. 2010. № 2. С. 82 - 89. 